\title{
Strategi Mencetak Siswa untuk Siap Menghadapi Era Revolusi Industri 4.0 dan Meningkatkan Semangat Belajar dengan Konsep Law of Attraction bagi Siswa SMA/Sederajat di Lingkungan Mathla'ul Anwar Pandeglang
}

\author{
Henri Henriyan Al Gadri ${ }^{1}$, Asep Sujana ${ }^{2}$, Eka Rosdianwinata $^{2}$
}

1, 2 Universitas Mathla'ul Anwar Banten

\begin{tabular}{l}
\hline Article History \\
\hline Received 17.09 .2019 \\
Received in revised form \\
26.11 .2019 \\
Accepted 03.12 .2019 \\
Available online 16.12 .2019
\end{tabular}

\begin{abstract}
STRATEGIES TO STRENGTHEN STUDENTS TO BE READY FOR THE INDUSTRIAL REVOLUTION ERA 4.0 AND INCREASE THE ENTHUSIASM OF LEARNING WITH THE CONCEPT OF LAW OF ATTRACTION FOR HIGH SCHOOL STUDENTS IN MATHLA'UL ANWAR PANDEGLANG. Devotion to this society is attempting to give students through the primary purpose of the workshop about the scored students for ready to face the industrial revolution 4.0 and increase eager to study with the the law of attraction concept. Things that are provided with for students is an understanding of the era of the industrial revolution 4.0, for students, mental maturation an injection motivation, and increase passion for being students who superior. These efforts becomes strategy in preparing students for ready to face the era of the industrial revolution 4.0. Strategies are delivered to students through the concept of the Law of Attraction. The concept was to give effect both mentally, foster self-confidence, mindset, spirit, determination, and an attitude to face something. The objectives of this workshop are: 1) scored students for ready to confront the industrial revolution $4.0 ; 2$ ) improve the quality of students that are highly competitive; 3 ) foster the understanding that the knowledge gained can be actualized in the community; 4) fosters an understanding of the use of digital technology and the Internet of things technology to boost productivity and competitiveness of students; 5) enhance the spirit of learning to boost student achievement.
\end{abstract}

KEYWORDS: Learning Media, Sparkol Videoscribe, Teachers Professionalism. Attribution 4.0 International License, which permits unrestricted use, distribution, and reproduction in any medium, provided the original work is properly cited. c 2019 Henri Henriyan Al Gadri, Asep Sujana, Eka Rosdianwinata.

\section{PENDAHULUAN}

Pendidikan sejatinya terancang dengan menyesuaikan tuntutan zaman. Keberadaan pendidikan sejalan dengan perkembangan zaman yang melibatkan berbagai unsur.

${ }^{1}$ Corresponding author: FKIP Universitas Mathla'ul Anwar Banten. Jalan Raya Labuan KM 23, Cikaliung, Saketi, Sindanghayu, Saketi, Kabupaten Pandeglang, Banten 42273, Indonesia. Email: henrialgadri@ gmail.com 
Sekolah sebagai penyelenggara pendidikan dituntut untuk fleksibel dan siap menyikapi perubahan dengan baik. Hal tersebut berimbas bagi siswa yang secara otomatis mengalami setiap perubahan. Oleh karenanya, banyak hal yang perlu disiapkan pendidik untuk mempersiapkan siswa dalam menghadapi tuntutan demi tuntutan yang disuguhka setiap masa.

Saat ini kita berada di era revolusi industri 4.0, era ini ditandai dengan hadirnya mekanisasi, automatisasi dan kecerdasan buatan. Revolusi Industri 4.0 menerapkan konsep automatisasi yang dilakukan oleh mesin tanpa memerlukan tenaga manusia dalam pengaplikasiannya. Saat ini, sudah bermunculan beberapa pabrik-pabrik di luar negeri maupun di dalam negeri yang memanfaatkan konsep automatisasi tersebut. Hadirnya teknologi tersebut dapat bermanfaat dari segi waktu, tenaga kerja, dan biaya. Penerapan Revolusi Industri 4.0 di pabrik-pabrik saat ini juga dikenal dengan istilah Smart Factory.

Menurut Satya (2018) Revolusi industri 4.0 adalah sebuah istilah yang diciptakan pertama kali di Jerman pada tahun 2011 yang ditandai dengan revolusi digital. Industri ini merupakan suatu proses industri yang terhubung secara digital yang mencakup berbagai jenis teknologi, mulai dari $3 D$ printing hingga robotik yang diyakini mampu meningkatkan produktivitas. Sebelum ini telah terjadi tiga revolusi industri yang ditandai dengan: 1) Ditemukannya mesin uap dan kereta api tahun 1750-1930; 2) Penemuan listrik, alat komunikasi, kimia, dan minyak tahun 1870-1900; 3) Penemuan komputer, internet, dan telepon genggam tahun 1960-sekarang.

Revolusi industri kedua dikenal sebagai Revolusi Teknologi. Revolusi ini ditandai dengan penggunaan dan produksi besi dan baja dalam skala besar, meluasnya penggunaan tenaga uap, mesin telegraf. Pada revolusi industri ketiga, industri manufaktur telah beralih menjadi bisnis digital. Teknologi digital telah menguasai industri media dan ritel. Revolusi industri ketiga mengubah pola relasi dan komunikasi masyarakat kontemporer. Revolusi ini telah mempersingkat jarak dan waktu, revolusi ini mengedepankan sisi real time. Revolusi industri keempat ini teknologi informasi dan komunikasi dimanfaatkan sepenuhnya. Pada era ini model bisnis mengalami perubahan besar, tidak hanya dalam proses produksi, melainkan juga di seluruh rantai nilai industri.

Di era revolusi industri 4.0 terdapat banyak inovasi baru, di antaranya cyber-physical system Internet of Things (IoT), Big Data, dan Artifical Intelligence (AI). Salah satu hal terbesar didalam Revolusi Industri 4.0 adalah Internet of Things. IoT (Internet of Things) memiliki kemampuan dalam menyambungkan dan memudahkan proses komunikasi antara mesin, perangkat, sensor, dan manusia melalui jaringan internet. Pemanfaatan internet dapat menyentuh beberapa bidang seperti pendidikan, ekonomi, teknik, kesehatan dan lain-lain.

Hadirnya era revolusi industri 4.0 menuntut masyarakat atau pekerja untuk memiliki daya saing tinggi tentunya dengan memiliki keterampilan mempuni dalam menghadapi kecanggihan di era revolusi industri 4.0. World Economic Forum telah merilis laporan yang mengungkap 10 keterampilan teratas yang dibutuhkan pada 2020. Keterampilan tersebut ialah Complex Problem Solving, Critical Thinking, Creativity and Innovative, People Management and Leadership, Coordinating with Others or Teamwork, Emotional Intelligence, Judgement and Decision Making, Service Orientation, Negotiation and Presentation, dan Cognitive Flexibility (Akhrizal, 2019). Selain 10 keterampilan tersebut, ada 
lima keterampilan lain yang juga penting dikuasai. Kelima keterampilan tersebut ialah, Kemampuan berbahasa Inggris dan public speaking, Pengoperasian komputer, Manajemen waktu, Bekerja secara mandiri, dan Kemampuan media sosial.

Keterampilan tersebut menjadi solusi dan bekal untuk mengahadapi era revolusi industri 4.0. keterampilan tersebut merupakan kempuan yang tidak bisa dikendalikan oleh robot. Dengan adanya era revolusi indutri 4.0 dapat mengancam bergeser hingga hilangnya beberapa pekerjaan lama yang dalam pengerjaannya secara konvensional. Sekaligus bermunculannya pekerjaan baru yang dalam proses kerjanya memanfaatkan teknologi digital dan internet.

Siswa harus mampu memenuhi kebutuhan zaman yang semakin pesat, apalagi di daerah yang notabene kota industri. Tetapi sekolah dan siswa yang daerahnya terdapat industri-industri berteknologi tinggi dengan didukung akses internet yang cukup cepat dan penggunaan teknogi digital, memberikan motivasi lebih bagi siswa untuk berorientasi ke arah itu. Dampak positif setidaknya dapat terasa bagi siswa yang lingkungannya berteknologi tingggi. Sedangkan daerah yang kurang tersebarnya industri-industri berteknologi tinggi, akses internet yang kurang dan penggunaan teknologi digital kurang akan berdampak kurang bagus bagi siswa dari segi pengaruh dan motivasi untuk berorientasi ke arah itu.

Banyak daerah di Indonesia yang secara populasi pertumbuhan teknologi industri digitalnya tidak terlalu banyak. Di antaranya pandeglang Banten, Pandeglang secara letak geografis berada di bagian paling barat pulau jawa dengan mata pencaharian rata-rata di sektor pertanian dan perikanan. Untuk pertumbuhan industri berteknogi digital kurang begitu banyak. Hal tersebut memberikan pengaruh kurang dirasakannya industri berteknologi digital bagi masyarakat. Oleh karena itu dirasa perlu memperkenalkan revolusi industri 4.0 bagi siswa-siswi di Pandeglang Banten.

Di Pandegalang terdapat organisasi masyarakat yang konsentrasi pada bidang keagamaan dan pendidikan, organisasi tersebut ialah Mathla'ul Anwar. Mathla'ul Anwar menaungi beberapa sekolah dari pendidikan dasar hingga pendidikan tinggi. Kontribusi dan eksistensinya sangat dapat dirasakan besar bagi masyarakat di Pandeglang. Terdapat sekolah menengah atas sedarajat yang ada dalam naungan Perguruan Mathla'ul Mnwar Pusat Menes di antaranya ialah SMA Mathla'ul Anwar dan Madrasah Aliyah Mathla'ul Anwar Pusat Menes. kurikulum pada sekolah-sekolah tersebut sudah menggunakan kurikulum 2013 dengan di dasari nilai-nilai keislaman sebagai pondasi karakter siswa.

Dengan dikenalkannya pemahaman tentang era revolusi industri 4.0 kepada siswa dapat berpengaruh dengan baik dari segi kesiapan siswa dalam mengahadapi perubahan zaman. Siswa sebagai penerus generasi tidak akan kaget dengan hadirnya era revolusi industri 4.0 karena telah dibekali dan disiapkan secara mental dan pemahaman.

Pemberian pemahaman era revolusi industri 4.0 kepada siswa dilakukan dalam bentuk workshop yang dihadiri siswa SMA sederajat yang ada di lingkungan Mathla'ul Anwar Pandeglang. Pemahaman era revolusi industri 4.0 disampaikan kepada siswa mengunakan konsep Law of Attraction. Konsep tersebut memberikan dampak yang cukup baik terhadap siswa dari segi mental, menumbuhkan rasa percaya diri, mindset, semangat, tekad, dan sikap menghadapi sesuatu. 
Dalam buku The Secret yang ditulis oleh Rhonda Byrne dikupas tuntas mengenai konsep Law of Attraction. Konsep ini telah banyak digunakan orang sukses dalam kehidupan mereka selama ini. Serta buku yang berkaitan dengan kecerdasan emosional dalam pengendaliannya tertuang dalam buku berjudul "Emotional Intelligence" pada tahun 1995 (Sujana, Rosdianwinata, \& Al Gadri, 2018, p. 409).

Konsep ini sebelumnya telah diterapkan pada penelitian Kami tentang "Makna Law of Attraction: Mengungkap Rahasia Minat Belajar Matematika Siswa" yang dibiayai Kemenristekdikti pada skema PDP. Untuk itu, program pengabdian kepada masyarakat yang akan dilakukan didasari penelitian sebelumnya.

Dari hasil peneletian mendapatkan temuan tentang permasalahan siswa dalam belajar. temuan tersebut didapat dari angket dan wawancara dengan siswa dan guru. Berikut ini temuan masalah yang dihadapi siswa dalam belajar:

1) Motivasi belajar;

2) Rasa percaya diri;

3) Kefokusan dalam belajar;

4) Kesulitan mengolah bahan ajar;

5) Kebiasaan buruk dalam belajar;

6) Tingkat kecerdasan rendah.

Temuan tersebut senada dengan yang dikemukakan Prayitno (1994, p. 90) bahwa masala-masah belajar ialah:

1) Keterampilan akademik, yaitu keadaan siswa yang diperkirakan memiliki intelegensi yang cukup tinggi, tetapi tidak dapat memanfaatkannya secara optimal.

2) Ketercepatan dalam belajar, yaitu keadaan siswa yang memiliki IQ 130 atau lebih tetapi masih memerlukan tugas-tugas khusus untuk memenuhi kebutuhan dan kemampuan belajar yang amat tinggi itu.

3) Sangat lambat dalam belajar, yaitu keadaan siswa yang memiliki akademik yang kurang memadai dan perlu dipertimbangkan untuk mendapatkan pendidikan atau pengajaran khusus

4) Kurang motivasi dalam belajar, yaitu keadaan siswa yang kurang bersemangat dalam belajar mereka seolah-olah tampak jera dan malas.

5) Bersikap dan berkebiasan buruk dalam belajar, yaitu kondisi siswa yang kegiatan atau perbuatan belajarnya sehari-hari antagonistik dengan yang seharusnya, seperti suka menunda-nunda tugas, mengulur waktu, membenci guru, tidak mau bertanya untuk hal-hal yang tidak diketahuinya dan sebagainya.

Permasalahan di atas menjadi perhatian khusus karena dapat mempengaruhi prestasi dan kualitas siswa. Perlu suatu tanggapan yang serius dalam menyikapi hal tersebut. Terlebih siswa harus memiliki daya saing tinggi mengingat perkembangan zaman yang tengah masuk di era revolusi industri 4.0. Bersama guru di sekolah mitra berupaya untuk menanggulangi permasalahn tersebut. Dengan perlunya ada suatu strategi yang harus dibekali untuk siswa agar mendokrak semangat belajar dan siap menghadapi era revolusi industri 4.0. 


\section{METODE PELAKSANAAN}

Program pengabdian masyarakat ini berbentuk workshop yang dilaksanakan pada 30 Juli 2019 dengan lokasi kegiatan di SMA Mathla'ul Anwar Menes, Pandeglang. Peserta kegiatan ini adalah siswa dari SMA Mathla'ul Anwar Menes dan Madrasah Aliyah Mathla'ul Anwar Pusat Menes.

Program pengabdian masyarakat ini dilakukan dalam tiga tahap, yaitu persiapan, pelaksanaan, dan pelaporan. Pada tahap persiapan, diawali studi pendahuluan dengan melakukan observasi guna mendapatkan pengetahuan awal mengenai masalah yang dihadapi sekolah mitra.

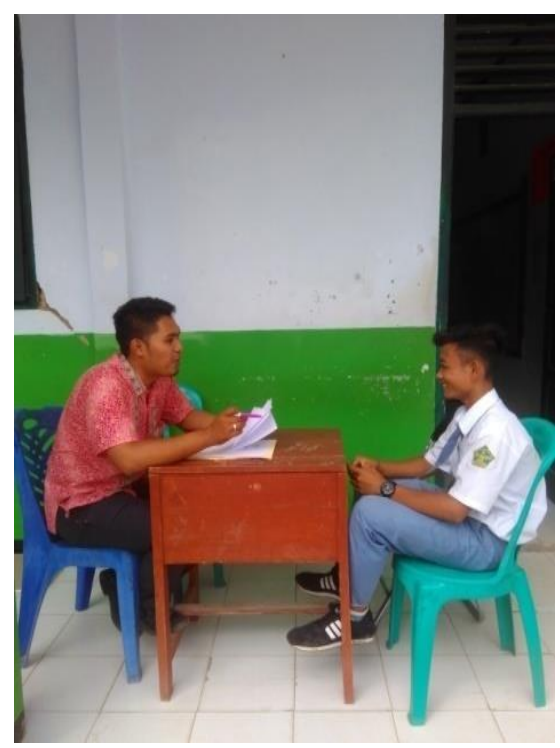

Gambar 1. Wawancara dengan Siswa di Sekolah Mitra

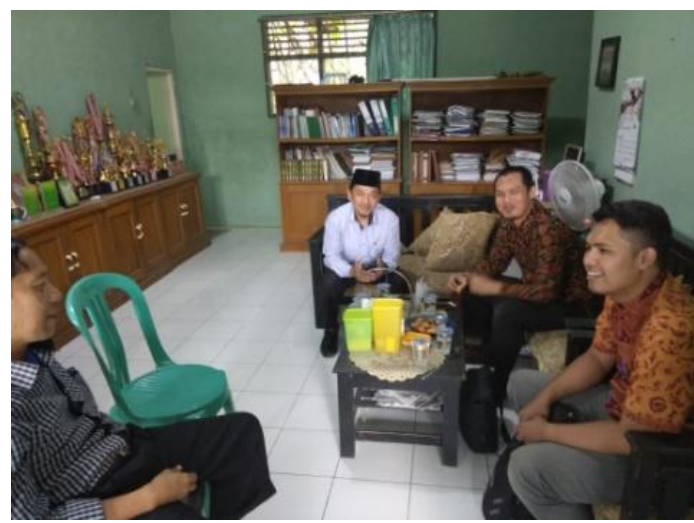

Gambar 2. Diskusi Bersama Mitra

Selanjutnya pada tahap pelaksaanan dalam bentuk workshop yang berjudul Stategi Mencetak Siswa untuk Siap Menghadapi Era Revolusi Industri 4.0 dan Meningkatkan Semangat Belajar dengan Konsep Low of Attraction bagi Siswa SMA/Sederajat di Lingkungan Mathla'ul Anwar Pandeglang. Langkah oprasional pada kegiatan tersebut ialah pemberian materi atau pemahan pada siswa tentang Era Revolusi Industri 4.0, Cara 
Meningkatkan Semangat Belajar dan Konsep Low Of Attraction. Harapat pada proses tersebut yaitu siswa siap mengahadapi era revolusi industri 4.0 dan meningkatnya semangat belajar. Tahap pelaporan dilakukan dengan membuat laporan pelaksanaan pengabdian masyarakan dan laporan penggunaan anggaran.

\section{HASIL DAN PEMBAHASAN}

Masalah yang dihadapi siswa-siswi di sekolah mitra menjadi dasar dalam melaksanakan pengabdian masyarakat. masalah tersebut didapat dari proses studi pendahuluan dalam bentuk observasi dan wawancara dengan guru dan siswa. Poin masalah yang muncul ialah:

1) Kurangnya pemahaman tentang revolusi industri 4.0;

2) Keadaan siswa yang diperkirakan memiliki intelegensi yang cukup tinggi, tetapi tidak dapat memanfaatkannya secara optimal;

3) Kurangnya rasa percaya diri siswa;

4) Butuh motivasi belajar lebih guna mendongkrak prestasi siswa;

5) Belum diadakannya kegiatan yang membahas tentang revolusi industri 4.0.

Temuan yang didapatkan di atas mendasari dirumuskan beberapa capaian pada program pengabdian masyarakat, yakni: 1) mencetak siswa yang siap mengahadapi era revolusi industri 4.0; 2) meningkatkan kualitas siswa yang berdaya saing tinggi; 3) menumbuhkan pemahaman bahwa ilmu yang didapat dapat diaktulisasikan di masyarakat; 4) menumbuhkan pemahaman tentang pemanfaatan teknologi digital dan teknologi internet of things untuk memacu produktivitas dan daya saing siswa; 5) meningkatkan semangat belajar untuk mendongkrak prestasi siswa.

Solusi untuk menuju capaian kegiatan pengabdian kepada masyarakat ini dengan cara memberikan pemahaman kepada siswa lewat kegiatan Workshop tentang Strategi Mencetak Siswa untuk Siap Menghadapi Era Revolusi Industri 4.0 dan Meningkatkan Semangat Belajar dengan Konsep Law of Attraction. Hal-hal yang dibekali untuk siswa ialah pemahaman tentang Era Revolusi Industri 4.0, Pematangan Mental bagi Siswa, Suntikan motivasi, dan meningkatkan semangat demi mendokrak kualitas siswa yang unggul.

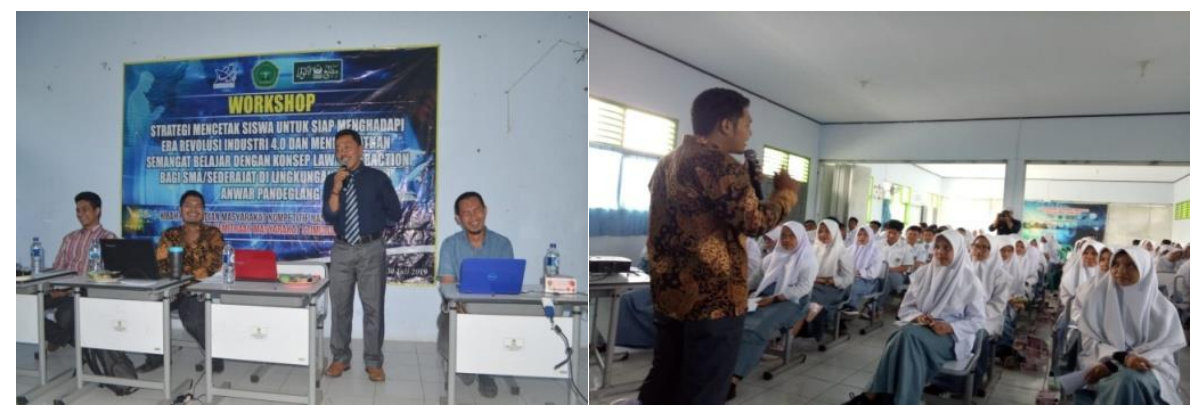

Gambar 3. Pelaksanaan Workshop

Pada saat materi, materi dibagi menjadi empat sesi. Materi pertama tentang “Konsep Law of Attraction". Materi tersebut dapat memberikan pengaruh yang baik dari segi 
mental, menumbuhkan rasa percaya diri, mindset, semangat, tekad, dan sikap menghadapi sesuatu. Konsep Law of Attraction dapat menumbuhkan mindset dan mental siswa untuk siap dan yakin bisa menghadapi era revolusi industri 4.0.

Sesi kedua membahas tentang "Mengenal Revolusi Industri 4.0 dan menyiapkan diri menghadapinya". Materi tersebut membahas tentang revolusi industri 4.0, teknologiteknologi di era revolusi industri 4.0, sejarah, dan keterampilan yang harus dimiliki dalam menghadapi era revolusi industri 4.0. Dari materi tersebut dapat memberikan pemahan kepada siswa tentang revolusi industri 4.0, sekaligus memberikan gambaran akan tantangan yang akan dihadapi di era revolusi industri 4.0 dan mengetahui keterampilanketerampilan apa saja yang harus dimiliki dalam mengahadapi era tersebut.

Sesi ketiga ialah materi "Meningkatkan semangat belajar sebagai bekal menghadapi Era Revolusi Industri 4.0". Materi ini siswa disajikan materi yang dapat memberikan pematangan mental bagi Siswa, suntikan motivasi, dan meningkatkan semangat belajar demi mendokrak kualitas siswa yang unggul. Kualitas siswa yang unggul menjadi modal berharga siswa dalam menghadapi era revolusi industri 4.0.

Sesi materi terakhir, yaitu tentang "Kiat Memanfaatkan Teknologi Internet dengan Baik" Materi tersebut memberikan pemahaman kepada siswa tentang menggunakan internet secara positif, menyampaikan peluang-peluang bergelut di dunia online, dan trik mendapatkan pendapatan di media sosial on-line.

Upaya tersebut menjadi strategi dalam menyiapkan siswa untuk siap menghadapi era revolusi industri 4.0. Strategi yang disampaikan kepada siswa melalu konsep Law of Attraction. Konsep tersebut dapat memberikan pengaruh yang baik dari segi mental, menumbuhkan rasa percaya diri, mindset, semangat, tekad, dan sikap menghadapi seseuatu. Siswa sebagai penerus generasi sangat perlu dipersiapkan untuk menghadapi era revolusi industri 4.0. di era ini sangat begitu mengedepankan kecanggihan teknologi. Baik dari teknologi digital, informasi, manufaktur dan penggunaan internet kebergai bidang.

\section{SIMPULAN}

Dengan dikenalkannya pemahaman tentang era revolusi industri 4.0 kepada siswa dapat berpengaruh dengan baik dari segi kesiapan siswa dalam mengahadapi perubahan zaman. Siswa sebagai penerus generasi tidak akan kaget dengan hadirnya era revolusi industri 4.0 karena telah dibekali dan disiapkan secara mental dan pemahaman.

Konsep Law of Attraction dapat memberikan pengaruh yang baik dari segi menumbuhkan rasa percaya diri, penguatan mental, mindset, semangat, tekad, dan sikap menghadapi sesuatu. Dalam konsep Law of Attraction, senantiasa menitikberatkan pada kekuatan pikiran yang dapat memengaruhi berbagai hal.

Meningkatkan semangat belajar dapat mendokrak prestasi dan kualitas. Kualitas siswa yang unggul menjadi modal berharga siswa dalam menghadapi era revolusi industri 4.0. 


\section{UCAPAN TERIMA KASIH}

Penulis mengucapkan terima kasih kepada Direktorat Jenderal Penguatan Riset dan Pengembangan (c.q Direktorat Riset dan Pengabdian Masyarakat) Kementerian Riset, Teknologi, dan Pendidikan Tinggi atas kempatannya melaksanakan Hibah Program Pengabdian Masyarakat Stimulus (PKMS) tahun anggaran 2019.

\section{REFERENSI}

Akhrizal. (2019). Era revolusi industri 4.0 tantangan baru guru PAUD. Retrieved November 10, 2019, from https://bit.ly/39n6C4x

Kemenperin. (2018). Making Indonesia 4.0: Strategi RI masuki revolusi industri ke-4. Jakarta: Kementerian Perindustrian RI.

Muhasim. (2017). Pengaruh tehnologi digital, terhadap motivasi belajar peserta didik. Jurnal Palapa, 5(2), 53-77.

Majelis Pendidikan Dewan Pendidikan Tinggi. (2017). Memandang revolusi industri dan dialog pendidikan karakter di perguruan tinggi Indonesia. Jakarta: Kementerian Riset, Teknologi dan Pendidikan Tinggi.

Prayitno, E. A. (1994). Dasar-dasar bimbingan dan konseling. Jakarta: Rineka Cipta.

Satya, V. L. (2018). Strategi Indonesia menghadapi industri 4.0. Info Singkat, 10(9), 19-24.

Sujana, A., Rosdianwinata, E., \& Al Gadri, H. H. H. (2018). Makna Low Of Attraction: Mengungkap Rahasia Minat Belajar Matematika Siswa. Prosiding SENAMKU, 1, 406417. 